\title{
A idéia de jogo em obras de John Cage e no ambiente da livre improvisação
}

\author{
Rogério Luiz Moraes Costa (USP, São Paulo) \\ rogercos@usp.br
}

\begin{abstract}
Resumo. Este texto examina as principais diferenças de enfoque relacionadas ao papel dos intérpretes na realização de duas diferentes propostas de jogo. Para tanto, são comparadas algumas obras de John Cage e as práticas de grupos que se dedicam à livre improvisação musical, principalmente do grupo Akronon. ${ }^{1}$ Procura-se demonstrar que as propostas de Cage, que estão situadas num plano conceitual, e as propostas da livre improvisação, que partem de uma prática experimental interativa baseada numa manipulação empírica dos sons, resultam em concepções bastante distintas a respeito do papel do intérprete. A partir desta perspectiva, afirma-se o caráter potente da livre improvisação que pode ser pensada enquanto prática de um jogo ideal conforme conceituação proposta pelo filósofo francês Gilles Deleuze.
\end{abstract}

Palavras-chave: John Cage, livre improvisação, jogo, performance musical, processos de criação, acaso e indeterminação.

\section{The idea of game in works of John Cage and in the environment of free improvisation}

Abstract. This text examines the main differences in approaching the role of interpreters in the realization of two different game proposals. Therefore, some works of John Cage and practices of groups active in the free improvisation music are compared, especially the group Akronon (to which the author of this article is a member). It is demonstrated that Cage's proposals, which are located in a conceptual plan and the proposals of free improvisation, which depart from a practice based on experimental interactive empirical manipulation of the sounds, result in very different conceptions about the role of interpreter. From this perspective, the vital and dynamic nature of free improvisation is stated, which can be conceived as a sort of ideal game according to a concept proposed by the French philosopher Gilles Deleuze. Keywords: John Cage, free improvisation, game, music performance, creative processes, indeterminacy and chance.

\section{1 - Introdução}

Ao examinarmos os textos e as obras de John Cage compostas principalmente a partir de 1950, percebemos a importância que o músico passou a atribuir aos processos de indeterminação e acaso na constituição de seu projeto composicional e estético. Trataremos aqui especificamente das conseqüências de suas idéias para uma suposta modificação do papel do intérprete na execução deste repertório. Faremos também uma comparação entre as propostas de jogo contidas nas obras deste período de sua produção e aquelas que surgem no ambiente da livre improvisação. ${ }^{2} \mathrm{~A}$ idéia que se tem é que, aparentemente, nessas obras de Cage o intérprete é chamado a participar de maneira criativa - quase como um cúmplice do compositor - dos processos composicionais através de seu engajamento em práticas de improvisação. No entanto, para nós esta afirmação parece estar longe do que de fato ocorre com relação à participação dos intérpretes. ${ }^{3}$

\section{2 - Cage e a livre improvisação: o conceito e o som}

Sabemos o quanto nesta época Cage se contaminou pelas idéias de não controle, uso do acaso e do silêncio. Estas idéias ganham corpo no projeto do compositor principalmente a partir de seu contato com a filosofia Zen Budista e com o I Ching. Um exemplo da sua identificação com esta filosofia e as conseqüências em seu pensamento sobre música podem ser percebidos no seguinte texto:

A primeira vez que eu ouvi uma conferência de Suzuki, com quem eu estava estudando a filosofia do Zen Budismo, foi sobre a estrutura da mente. /.../ Através do Zen, alguém poderia se liberar dos seus gostos e desgostos, da memória, deixando a mente fluir. |.../ Eu decidi não deixar de escrever música e não disciplinar 0 meu ego sentado com as pernas cruzadas, mas encontrar um meio de escrever música tão severamente em relação ao meu ego como sentar de pernas cruzadas (apud, KOSTELANETZ, 2000, p. 177). 
Acreditamos que, em certa medida, podemos considerar sua obra desse período como um projeto de concretizar em propostas musicais o pensamento Zen. Em outras palavras, poderiamos dizer que Cage trata de tornar sonoro o pensamento Zen. A partir deste projeto, conforme observa Boulez 4 de forma irônica em seu artigo Alea, Cage abre mão da idéia de controle nos seus processos composicionais e adota o acaso, os processos aleatórios e a indeterminação nas suas diversas formas, como um meio de definir vários aspectos de suas composições.

Não se trata em nosso texto de, à maneira de Boulez, desqualificar a contribuição estética e filosófica de Cage nem de desconsiderar seu papel fundamental no que diz respeito à proposição de novas formas de escuta e prática musical. Umberto Eco, por exemplo, afirma já em 1959 que

\begin{abstract}
Cage é o profeta da desorganização musical, o sumo sacerdote do acaso: a desagregação das estruturas tradicionais que a nova música serial procura como uma decisão quase científica encontra em Cage um eversor desprovido de qualquer inibição (ECO, 1976, p. 212) e que se no plano musical pode-se discutir eficazmente a respeito do destino da nova música, se reside no completo abandono à felicidade do acaso ou na disposição de estruturas "abertas", todavia orientadas segundo módulos de possibilidade formal: mas no plano filosófico, Cage é intocável, sua dialética Zen perfeitamente ortodoxa, sua função de pedra de escândalo e de estimulador de inteligências sopitadas inigualável. E é o caso de perguntar se ele está contribuindo para o esoterismo Zen ou para o campo musical, procurando uma lavagem mental de hábitos musicais adquiridos (idem, ibidem, p. 213).
\end{abstract}

A nossa intenção neste texto é investigar quais são as conseqüências de suas propostas relacionadas à atuação do intérprete. No que diz respeito à performance propriamente dita, o projeto de Cage é realizado principalmente através de propostas de jogo colocadas para os intérpretes. ${ }^{5} 0$ que desejamos ressaltar é que neste jogo, a princípio, o que importa não é o som. Ou melhor, o som pode ser um dos possíveis, porém imprevisíveis desdobramentos deste jogo que se instaura a partir das propostas formuladas por Cage. Assim, acreditamos poder afirmar que Cage propõe processos lúdicos onde o jogo se dá sobre conceitos ou sobre imagens e que nesses processos o som, ao contrário da improvisação livre, é secundário. ${ }^{6}$ Segundo Maria Helena Dal Pozzo, há na obra de Cage várias situações onde o intérprete é chamado a participar de maneira mais ou menos ativa. Podemos ler em sua tese de doutorado que

Cage acaba delegando maior liberdade ao intérprete através da omissão de informações na partitura ou do uso de gráficos ou desenhos, deixando um ou mais elementos ambíguos. No caso de omissão de informações, encontramos um exemplo na notação BE do Concert for Piano, que especifica os dedos, mãos ou braços que devem tocar, mas não especifica as alturas, durações, dinâmicas e ataques do som a ser produzido/.../Em Variations III, o intérprete deve manipular vários círculos de diferentes tamanhos sobre uma folha de papel. A interpretação do desenho formado pela sobreposição dos círculos é deixada bastante vaga nas instruções de Cage/.../ Encontramos outro exemplo desta ambigüidade na notação $A R$ do Concert for Piano, onde a única instrução fornecida é "toque qualquer coisa que o desenho sugerir". (DAL POZZO, 2007, p. 82, 83).
Já nas propostas de livre improvisação a interação entre os músicos se dá a partir de manipulações sonoras concretas e não a partir de formulações conceituais. Sobre este aspecto da livre improvisação pode-se dizer que

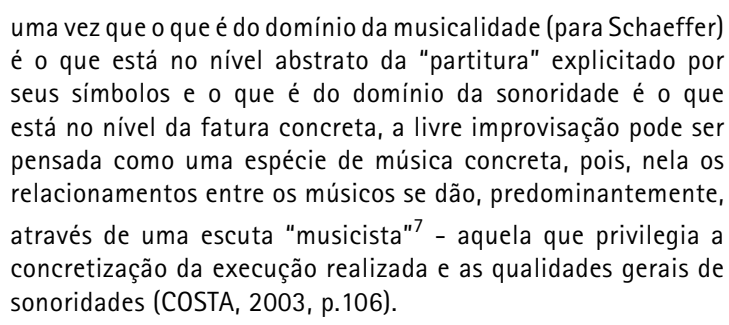
seus símbolos e o que é do domínio da sonoridade é o que está no nível da fatura concreta, a livre improvisação pode ser pensada como uma espécie de música concreta, pois, nela os relacionamentos entre os músicos se dão, predominantemente, através de uma escuta "musicista"7 - aquela que privilegia a concretização da execução realizada e as qualidades gerais de sonoridades (COSTA, 2003, p.106).

Neste sentido, apesar de muitas vezes se tentar estabelecer uma analogia entre o pensamento de Cage e dos artistas plásticos filiados ao expressionismo abstrato americano (Pollock, Rauschenberg, Calder etc.), acreditamos que não há como sustentar esta relação, uma vez que, na maior parte das vezes, para estes artistas o processo de não controle e incorporação do acaso se dá a partir de uma manipulação "empírica" do material (cor, tinta, tela, pincel etc. ${ }^{8}$ ) e não a partir de formulações conceituais. Este equívoco se evidencia na analogia que o compositor americano Earle Brown procura estabelecer entre as suas propostas (contidas em peças como December 52, Folio, 25 pages e From Here, compostas a partir de procedimentos similares) e as obras dos artistas plásticos Alexander Calder e Jackson Pollock. Podemos ler em uma nota do compositor contida na partitura da peça From Here:

\begin{abstract}
Para mim, o conceito de elementos móveis, foi inspirado pelos móbiles de Alexander Calder, nos quais, similar às suas obras, existem unidades básicas sujeitas a diferentes e inumeráveis relações ou formas. 0 conceito de obra espontaneamente criada durante a execução foi originalmente inspirado pelas técnicas de 'action painting' em obras de Jackson Pollock do final dos anos 1940, nas quais o imediatismo e a franqueza do contato com o material têm grande importância, produzindo uma exploração e um resultado de grande intensidade. As condições de execução destas obras são similares ao trabalho espontâneo do pintor com uma dada paleta (apud, DAL POZZO, 2007, p. 129).
\end{abstract}

Quando lemos que a peça "December 1952 utiliza notação gráfica, consistindo em 31 blocos horizontais e verticais, de diferentes comprimentos e grossuras espaçadas sobre uma única folha", que "estes blocos não têm significado musical específico, podendo indicar altura, intensidade, duração ou outros parâmetros" e que "a partitura pode ser ainda lida em qualquer sentido portanto em quatro diferentes posições - e a obra tem duração indeterminada" (idem, ibidem, p. 128) podemos observar que o que de fato ocorre é um jogo conceitual (apoiado nas imagens e instruções contidas na partitura) e não um trabalho direto onde, como afirma Earle Brown o imediatismo e a franqueza do contato com o material têm grande importância.

A esse respeito vale ressaltar que é notória a despreocupação de Cage (e dos continuadores da tradição experimental americana tais como Earle Brown) com relação ao resultado sonoro de suas propostas. Nas instruções aos 
intérpretes, quando há referências ao som, estas são em geral, ambíguas, vagas e relacionadas à idéia abstrata de nota (altura e duração). 0 resultado sonoro das propostas é, na maior parte das vezes, irrelevante. ${ }^{9}$

Outra importante diferença reside no fato de que, no jogo que envolve os intérpretes, Cage se comporta como $\mathbf{o}$ formulador de regras enquanto na livre improvisação as regras são formuladas no devir do próprio jogo. Isto significa que não há regras a priori e que a livre improvisação é muito mais um plano imanente de criação. Em nossa tese de doutorado já havíamos discutido este assunto que aqui nos propomos a aprofundar. Lá podemos ler o seguinte: "Cage é assim. Ele deixa as respostas em aberto. Mas é sempre ele quem faz as perguntas. E quem faz as perguntas imagina um quadro de respostas" (COSTA, 2003, p. 206). Assim, nas propostas de Cage, o jogo tem uma formulação conceitual, fechada e programada (apesar de muitas vezes se apresentar de forma ambígua e paradoxal) enquanto na improvisação livre o processo se dá a partir da interação entre as vontades enunciativas dos intérpretes-criadores envolvidos no processo. Com o cuidado de reiterar que estamos apenas comentando a situação do intérprete no contexto destas obras e que com isso não queremos concluir nada a respeito das outras questões musicais ou conceituais enfrentadas nas mesmas, parecenos que no jogo de Cage, a explicitação de regras geradas em processos composicionais que incorporam a indeterminação e/ou o acaso - intencionalmente conceituais, ambíguas, paradoxais e inexatas, torna a participação dos intérpretes artificial e na maior parte das vezes instaura um ambiente onde se perde a potência de enunciação individual e coletiva. Mesmo quando ele afirma que "aqui e em qualquer lugar, a ausência de indicações de qualquer tipo, significa liberdade para o intérprete a este respeito" (DAL POZZO, 2007, p. 97). Às vezes a impressão é de que se trata de um jogo complicado que quase ninguém quer jogar. 0 jogo de Cage acontece muito mais no âmbito da partitura (que, conforme pudemos observar nos exemplos anteriores, muitas vezes é uma imagem gráfica que tem o intuito de "incentivar" o intérprete a participar do jogo) do que numa real proposta de participação dos músicos. ${ }^{10}$ Vale ressaltar que, para nós as propostas de jogo na obra de Cage estão mais ligadas às suas reflexões sobre o deslocamento da escuta e da própria idéia de música e de arte, do que a uma preocupação com um reposicionamento do intérprete. Nesse sentido, torna-se evidente a primazia do conceitual diante do sonoro. Do nosso ponto de vista não há, apesar das intenções explicitadas, neste paradoxal jogo cageano, uma verdadeira proposta de liberdade e participação para o intérprete.

É igualmente falha a relação que se tenta estabelecer entre as propostas de Cage e aquelas dos artistas ligados ao movimento surrealista (André Breton, Salvador Dali etc.) tais como as idéias de fluxo do inconsciente e automatismo. Para o intérprete das obras de Cage não se trata exatamente de trabalhar a partir dos fluxos do inconsciente. Ele deve sim responder de maneira relativamente aberta e paradoxal às instruções e regras estabelecidas por Cage. Na verdade, a liberdade de se trabalhar a partir dos fluxos do inconsciente não pode ser concedida por um compositor. Ela depende de uma atitude do intérprete que se coloca na situação de criador. Num certo sentido, trata-se de uma conquista do intérprete. ${ }^{11}$ Sobre isso, Boulez afirma com sua habitual mordacidade: "supondo que os intérpretes sejam imaginativos, eles deveriam ser então compositores..." (apud NATIIEZ, 1993, p. 116-117). Já na livre improvisação a analogia com o surrealismo é certamente mais promissora. No seu artigo sobre as possiveis relações entre o surrealismo e a música pós moderna, Anne LeBaron afirma que

\footnotetext{
Uma vez que o automatismo é um dos componentes fundamentais do surrealismo, ele deveria ter uma contraparte musical/.../0 automatismo, a liga que molda a infra-estrutura do surrealismo, tem seu mais direto paralelo musical na livre improvisação. Eu a defino como uma improvisação não idiomática que incorpora uma unidade entre mente e ação: concepção musical e performance acontecem simultaneamente. Ao acessar o inconsciente da maneira mais imediata e direta, a improvisação musical não idiomática pode possibilitar uma transferência ainda mais rápida do inconsciente em produtos sensoriais (sons, neste caso) do que no automatismo literário ou visual (LE BARON, apud LOCHHEAD, 2005, p. 35).
}

Isso não quer dizer que Cage não tenha intenções claras relacionadas à atuação do intérprete. Ele quer colocá-lo em uma situação de risco. Quer provocá-lo, desestabilizálo, deslocar seu centro, questionar suas certezas. Parecenos, no entanto, que no caso específico da participação criativa dos intérpretes, Cage adota uma postura, por assim dizer, paternalista. Ele parece querer obrigar 0 intérprete a participar de um processo de criação a partir da formulação de regras arbitrárias e exteriores, ou seja, desvinculadas de qualquer contexto musical idiomático específico. Porém, o intérprete só se torna criador quando se vê diante de um ambiente propício (como discutiremos com mais profundidade no decorrer deste artigo). Além disso, o móvel da improvisação é justamente o desejo: o desejo de criar, de ser o formulador de seu próprio discurso, de participar de maneira criativa de um jogo, de exercer de maneira autônoma o pensamento musical. Essa idéia nos parece fundamental para explicar as diferenças entre as duas propostas aqui abordadas, inclusive no que diz respeito às suas origens históricas. No caso de Cage, o intérprete (em geral ligado à tradição erudita e à prática musical através da mediação da partitura) é convidado a participar e ser criativo. Já nas várias formas de improvisação idiomática ou livre, o intérprete está, na maior parte das vezes, imerso numa prática musical onde não há a mediação de uma partitura. Sua participação se dá no contato direto com os materiais sonoros produzidos neste ambiente. Por isso, a improvisação funciona muito bem em ambientes idiomáticos como no jazz, no choro, na música hindu e na música flamenga. Lá o improvisador se sente participando de maneira ativa de um jogo coletivo, 
com regras implícitas e culturalmente determinadas. Seu corpo está presente no ato enunciativo, performático. Por isso, a improvisação se dá como vimos anteriormente, como uma espécie de música concreta, empírica, que depende de uma relação intensa de escuta e de intimidade com o instrumento, pensado aqui como uma espécie de prolongamento da voz do músico.

\section{3 - 0 jogo da livre improvisação: uma música concreta}

Já sabemos: na livre improvisação o que importa é o processo (assim como nas propostas de jogo de Cage). A noção de obra, a noção de autoria é irrelevante para os participantes de uma performance de livre improvisação. Talvez cada grupo encontre uma assinatura, um estilo de jogo, um entrosamento próprio. Tomando por base a nossa experiência com o grupo Akronon, podemos afirmar que na livre improvisação coletiva se cria um ambiente de relação e conversa, de fluxo e fluidez. Sucedem-se estados provisórios de diferentes consistências. Há vários vetores, forças e fatores que interagem neste ambiente no momento mesmo de uma performance (tais como, o formato da sala, a presença ou não de um público, o nivel de entrosamento entre os participantes, o estado de ânimo dos improvisadores, suas biografias e vivências musicais e pessoais, a técnica de cada instrumentista, o estado de conservação dos instrumentos etc.), porém a "espessura" da performance tem seu centro na escuta e nas interações entre os fluxos sonoros emitidos e modulados pelos músicos.

Estes fluxos sonoros podem ser de naturezas diferentes. ${ }^{12}$ Há um pensamento mais melódico (rítmico-intervalar). 0 compositor inglês Brian Ferneyhough diria que este é um pensamento figural. Este tipo de escuta remete às relações entre as figuras, possibilita a idéia de motivo, tema, desenvolvimento etc. (os improvisadores de jazz trabalham intensamente com este tipo de pensamento). Poderíamos detalhar esta idéia dizendo que há um pensamento mais "puramente" rítmico (que se baseia em algum tipo de agenciamento sobre o eixo do tempo: liso ou estriado). Este pensamento é abstrato, porém se realiza sobre alguma materialidade: o "puramente" rítmico precisa do suporte concreto para se estabelecer. Pensemos em uma batucada de samba: poderíamos, abstraindo a sonoridade revelar sua estrutura ritmica subjacente. Cage por exemplo, pensa algumas de suas peças somente do ponto de vista rítmico: a realização (a música en temps) pode se dar sobre qualquer suporte sonoro.

$\mathrm{Na}$ conjunção e entrecruzamento destes dois tipos de pensamento num contexto específico (cultural, territorial, técnico) pode se manifestar um pensamento gestual que remete ao musical de Schaeffer. Trata-se de um pensamento musical que evoca "símbolos", significados diversos: um estilo, gênero, espécie, compositor (barroco, choro, valsa, be bop, Chopin etc.). Ou então, a uma forma de fatura instrumental específica. No gestual encontramse os vários idiomas. Neste caso as figuras se consolidam em "significados" nos contextos destes idiomas. Quando em um ambiente de livre improvisação ocorrem os gestos quase inevitáveis, eles se inserem e interferem no fluxo interativo a partir de suas qualidades "históricas" e idiomáticas. Porém, se prestam a operações variadas de desterritorialização e acabam se tornando materiais maleáveis para agenciamentos não idiomáticos. Podemos citar como exemplo desta situação, o aparecimento de um fraseado rítmico melódico originário do choro popular brasileiro que é aos poucos fragmentado e transformado durante a performance e acaba sendo utilizado num contexto em que aparece como um componente de uma textura complexa. Neste caso acontece, uma desterritorialização de um gesto e sua reterritorialização como figura, numa textura complexa.

Por último, há um pensamento mais voltado para o sonoro. 0 som não semântico, não inserido a priori em alguma estrutura musical pré-significante. 0 som enquanto manifestação de energias ainda não formadas: resultado de uma escuta reduzida ${ }^{13}$ schaefferiana. 0 som enquanto matéria prima básica inarticulada, movente, metamorfoseante, dinâmica, resultado da interação dinâmica entre os músicos e entre eles e o ambiente.

0 músico, numa performance de improvisação (mesmo na idiomática que supõe uma gramaticalidade abstrata explícita ou implícita) está sempre mergulhado ${ }^{14}$ num universo sonoro concreto. Mesmo que esteja imbuído de um projeto figural, supostamente abstrato (desenvolver idéias melódicas sobre uma base harmônica, por exemplo) ele nunca deixará de se deparar com a imediaticidade do som através do qual realiza suas idéias eventualmente premeditadas anteriormente num nível mental. Não há para ele, a mediação da partitura que fixa o pensamento musical numa dimensão atemporal e que possibilitaria o planejamento e as revisões. A memória do músico improvisador é um dos vetores fundamentais da performance e tende a ser uma memória de curto prazo condicionada por uma intrincada rede de afecções, sensações e intensidades que se desdobram no momento complexo do jogo. Cada momento da performance se configura de maneira única e irrepetivel. Os músicos resolvem problemas na hora em que eles ocorrem. Neste ambiente o músico tem que lidar com problemas técnicos de seu instrumento, com o fluxo sonoro que ele enuncia no presente e com o que surge das interações com os outros músicos. Neste sentido o resultado da livre improvisação tomando por base nossa experiência no grupo Akronon - pode possibilitar o surgimento daquilo que o filósofo francês Gilles Deleuze denomina como singularidade. Poderíamos definir este conceito como um

espaço de encontro das forças que não remete a uma interioridade ao fechamento sobre si, dentro de um eu, mas a um encontro com o outro - a arte funda sempre um novo lugar de troca, fora do sistema comum característico do discurso - espaço de intensidades e não representações, movimento do devir, no que ele tem de indeterminado e imprevisivel (BRITTO, 2007, p. 102). 


\section{4 - A idéia de jogo ideal e o desejo como potência na livre improvisação}

Sabemos que, tanto as propostas de participação do intérprete formuladas por John Cage quanto a prática da livre improvisação, se fundamentam na idéia de jogo. Segundo Johan Huizinga o jogo se coloca antes mesmo da linguagem. Para ele:

\begin{abstract}
"o jogo é mais antigo que a cultura /.../ Na forma e na função do jogo, que em si mesmo é uma entidade independente desprovida de sentido e racionalidade, a consciência que o homem tem de estar integrado numa ordem cósmica encontra sua expressão primeira" (Huizinga, 1993, p. 3, 21):
\end{abstract}

A partir dessas formulações de Huizinga podemos entender que o jogo está na origem da própria atividade do vivo. "É através do jogo que, o vivo se coloca em movimento, se desloca, adquire dinamismo, interage, se acomoda ou se adapta às várias situações reais (Costa, 2003, p. 53)". No entanto, devemos diferenciar a aplicação deste conceito quando o relacionamos à prática da livre improvisação, ao menos da perspectiva em que nos colocamos no grupo Akronon. Neste caso nos aproximamos da idéia de jogo ideal conforme formulação de Gilles Deleuze:

\begin{abstract}
Deleuze nos diz que não basta opor um jogo 'maior' ao jogo menor do homem, nem um jogo divino a um jogo humano. Para instaurar este jogo ideal é preciso imaginar outros princípios, aparentemente inaplicáveis, mas graças aos quais o jogo se torna puro. Ao contrário do jogo 'menor', neste não há regras preexistentes. Todas as jogadas são possíveis, pois cada lance inventa suas regras. Sem a intenção de dividir o acaso em um número de jogadas distintas, o conjunto de jogadas afirma todo acaso e o ramifica em cada jogada. No jogo ideal, portanto as jogadas não são numericamente distintas. Elas têm qualidades distintas, "todas são as formas qualitativas de um só e mesmo lançar ontologicamente uno." Assim também é a improvisação livre: um jogo dos problemas e da pergunta e "não do categórico e do hipotético". 0 jogo ideal e a livre improvisação são como a realidade do próprio pensamento. Este conceito de jogo ideal se opõe ao conceito genérico estabelecido por Huizinga que diz que uma das principais caracteristicas positivas do jogo é que ele cria ordem e é ordem. Introduz na confusão da vida e na imperfeição do mundo uma perfeição temporária e limitada, exige uma ordem suprema e absoluta: a menor desobediência a esta "estraga o jogo". Assim, parece que o jogo ideal é o próprio jogar em que ainda não se formalizaram regras. Ele é, nas palavras de Deleuze, um ritornelo primordial de territorialização anterior à própria territorialização. Nestes termos, esta nos parece ser a diferença entre a improvisação idiomática /.../ e a nossa proposta de uma improvisação não idiomática...(COSTA, 2003, p. 53, 54).
\end{abstract}

Podemos abordar esta idéia por um ponto de vista complementar afirmando que o jogo da improvisação livre põe em ação a vontade criativa dos músicos, ${ }_{1}^{15} 0$ desejo de atuar num ambiente pleno de virtualidades onde as matérias ainda não estão formadas. Já, para jogar 0 jogo de Cage é preciso adentrar num universo regrado e já conceitualmente imaginado a priori (e neste sentido paradoxalmente, controlado). ${ }^{16}$ Assim, devido ao fato de a improvisação se constituir enquanto um campo de virtualidades $^{17}$ imanentes, ela depende das vontades de potência dos músicos envolvidos para que haja atualizações extensivas de materiais perceptiveis. Neste ambiente, antes que haja as atualizações há os ritmos intensivos e inomináveis. Para iluminar o nosso entendimento sobre estas idéias de virtualidade e de intensividade que constituem o ambiente da improvisação podemos citar 0 trabalho de Rodrigo Rodrigues a respeito da escuta:

Os ritmos intensivos nos "trabalham, muito antes de nos darmos conta deles/.../quando escutamos (ou no nosso caso, improvisamos), somos afetados por um mundo de virtualidades insensíveis silenciosas, por uma realidade que é primordialmente vibratória, por fluxos heterogêneos compostos tanto de ritmos intensivos e não mensuráveis, quanto de ritmos extensos, quer dizer, percebidos e qualificados como matérias formadas no espaço-tempo. Isso quer dizer que os virtuais agem e se encarnam no mundo sensível, mas são silenciosos, jamais dados na experiência (RODRIGUES, 2007, p. 50).

Neste ambiente de virtualidade onde não há a representação abstrata, extensiva mediando o contato do músico com o som, com a escuta e o silêncio, o músico deve se propor a um mergulho num tempo intensivo, num tempo de diferenças puras. Isto é, na livre improvisação só existem as diferenças intensivas. Não há repetições. $A$ única repetição é a do desejo, da intensidade, do devir, da potência de futuro. E tudo isto depende, primordialmente (mas não só) dos músicos em interação. Obviamente, há o perigo de a improvisação estar povoada pelos gestos, clichês pessoais e condicionamentos das linguagens que abririam espaço para a repetição infecunda do mesmo. Isso seria sinal de que esta prática perdeu a sua potência, sua razão mesma de existência.

\section{5 - 0 ambiente do jogo ideal: relato de uma performance de livre improvisação}

Para ilustramos o ambiente da livre improvisação onde se torna possivel a idéia de jogo ideal e onde o músico deixa de ser intérprete de algo para ser formulador de seu próprio discurso, citaremos aqui, um longo trecho onde é descrita uma das muitas performances do grupo Akronon realizadas e gravadas $^{18}$ no ano de 2002. A descrição da performance se utiliza das categorias criadas por Pierre Schaeffer no contexto de suas formulações sobre a escuta reduzida e a tipo-morfologia do objeto sonoro. Tão importante quanto a descrição da performance sob o aspecto sonoro são as considerações sobre as formas de atuação e interação estabelecidas entre os músicos durante este jogo ideal.

Esta performance tem 9'17" de duração e foi uma das últimas realizadas pelo grupo no ano de 2002 (12/08/2002) /.../A sessão se inicia (0'00") com a superposição de dois objetos musicais contínuos e iterativos que se constituirão enquanto materiais energéticos geradores. Eles estão separados espacialmente, cada um em uma das caixas acústicas. Do lado direito, um objeto de aspecto rítmico aleatório e de freqüência indefinida numa região mais grave do espectro. É possivel a identificação da fatura instrumental: percussão com a ponta dos dedos no tampo do violino. Do lado direito, um objeto do mesmo tipo numa região mais aguda do espectro. Este é produzido pelo ruido da percussão das chaves no corpo do saxofone. A partir de um diálogo ${ }^{19}$ livre que põe em jogo estes dois objetos, se estabelece um fluxo sonoro complexo agenciado por procedimentos rítmicos caóticos. Surge então uma espécie de polifonia rítmica aleatória de densidade crescente. É mais fácil caracterizá-la pelas ausências do que pelas presenças: não há pulsos regulares e 
consequentemente não se estabelecem proporcionalidades, células, repetições, séries ou figuras identificáveis. A presença é a da variação contínua. É possível, portanto, definir estes procedimentos instrumentais enquanto vivências percussivas puras não mediadas pela proporcionalidade do pulso regular e por isso caóticas e imprevisiveis. Notemos que os procedimentos instrumentais apontam para uma idéia de instrumento expandido uma vez que não predomina uma gestualidade instrumental tradicional. Inventase uma nova técnica para a criação de novos sons. Uma tentativa de solfejo destes objetos com base no Tratado de Schaeffer nos aproxima novamente das categorias de amostra ou acumulação |.../ Por outro lado, esta sobreposição de objetos sonoros iterativos irregulares - amostras, acumulações - gera um grande objeto complexo e evolutivo que assume um aspecto aproximado ao de uma trama mista conforme definição de Pierre Schaeffer/.../As primeiras intervenções do aparato eletro-acústico (0'47") operam transformações nesta trama que acarretam uma ampliação ainda maior do espectro e da densidade. Até a marca de 1'10" portanto o aspecto da performance não só corresponde à categoria das tramas mistas como também esta trama aparece formada localmente por amostras e acumulações. Esta trama, objeto homogêneo, estável em sua variabilidade vai evoluir: ampliando o seu espectro, principalmente em direção aos graves (as chaves graves do saxofone produzem sons que, processados, se assemelham aos sons de tambores), densificando-se ritmicamente e incorporando um crescendo de intensidade. Gradualmente, a performance vai sofrer modificações mais significativas. Na marca de 1'11", introduzemse sonoridades novas: as cordas do violino são friccionadas levemente, evento este que aponta para o surgimento, mais tarde, de objetos com alturas definidas. Em seguida, se instala por pouco tempo - do 1'11' até o 1'25" - uma pulsação regular a partir de um gesto repetitivo de percussão nas chaves do sax. É um breve momento que não se estabelece, mas que surge enquanto potência - virtualidade - no fluxo da performance. Este tipo de "momento étnico" vai acontecer frequentemente no decorrer da sessão quando a textura vai assumir um aspecto que evoca difusamente, devido a procedimentos repetitivos, os universos gestuais idiomáticos. Isto porque a aparência das texturas nos territórios idiomáticos se caracteriza pela redundância e pela repetição periódica de elementos. Da marca de 1'25" até 2 '25" há uma grande transição ${ }^{20}$ em que ocorrem várias pequenas turbulências na textura original: diluições, silêncios e o estabelecimento de pequenas regularidades e desenvolvimentos figurais a partir de procedimentos de pergunta e resposta (por exemplo na marca de 1'48" até 1'56"). A transição conduz a um saturamento que desemboca em uma nova textura que vai se configurar a partir da introdução de um novo objeto iterativo pela flauta. Este objeto surge como conseqüência dos objetos iterativos anteriores, porém vai aos poucos incorporando o elemento frequencial e se estabelecendo enquanto objeto descontínuo, delimitado pelo fôlego do instrumentista - por isto de caráter gestual. Podemos resumir esta análise a uma visão mais genérica da performance. Todo o processo se dá de forma orgânica: revezam-se momentos mais "organizados" e homogêneos em que se identificam objetos sonoros mais estáveis, com momentos de saturação e diluição dos objetos (desequilibrio do organismo, desterritorialização). Geralmente, após estes momentos de desequilíbrio, ocorre uma espécie de realinhamento e uma reorganização de materiais (refazem-se objetos identificáveis, há uma reterritorialização). Os cortes ou transições se dão através do surgimento de materiais novos ou de silêncios como no caso da intervenção da flauta a partir do 2'25". Determinados eventos "fortes" (...eventos contrastantes no contexto e de pronunciada personalidade como é o caso desta intervenção rítmica da flauta), se transformam em centros /.../ em torno dos quais se organizam novos procedimentos. Se estabelecem então diálogos/interações que podem se caracterizar pelo desejo de contrastar, imitar, somar responder, etc. (respostas e propostas). Eventualmente, estes mesmos eventos fortes apontam para determinadas direções que acabam por não se concretizar. Assim, a imprevisibilidade está presente em todo percurso da performance. A sensação é de retrocausalidade: os objetos se configuram enquanto resultado de processos caóticos, as causas se verificam a posteriori. As causas não apontam para resultados unívocos (COSTA, 2002, p.175-180).

\section{6 - Conclusão}

Acreditamos que as propostas de jogo formuladas por Cage, na maior parte das vezes não conduzem 0 intérprete ${ }^{21}$ a assumir uma atitude próxima ao do compositor. Pelo contrário, apesar das suas aparentes intenções $^{22}$ no sentido de redimensionar o papel do instrumentista na execução das obras tornando-o assim um cúmplice do processo criativo, observamos que suas propostas, geralmente colocadas num plano conceitual muitas vezes acabam por afastar os intérpretes de qualquer envolvimento prazeroso (e por isso, instigante, potente, desejante) com o pensamento musical. Cage propõe um envolvimento com o conceito, com a imagem, com a analogia e não com o sonoro, com o temporal. Do nosso ponto de vista, na maior parte dessas peças Cage não prepara ${ }^{23}$ um ambiente sonoro acolhedor onde 0 intérprete possa se tornar formulador, criador ou agente de um processo de consistência baseado na experiência empírica com o som. As propostas de Cage deixam os intérpretes duplamente órfãos - com o que há de positivo e negativo nesta situação - na medida em que os afastam dos sistemas musicais que serviriam de base a um eventual jogo musical idiomático - como os que se estabelecem nos territórios da improvisação idiomática - e, também não propõem, ao contrário da improvisação livre, uma experiência empírica, concreta com o som tomado enquanto força molecular plena de dinamismos (como diriam os compositores Giacinto Scelsi e Edgard Varèse).

Já na improvisação idiomática (aquela que tem nome e território bem delimitado, por exemplo, o jazz, a música hindu, o flamengo etc.) se dá uma situação bem diversa. 0 intérprete é quem realiza as possibilidades de jogo que existem em potência no idioma que, por sinal é resultante dinâmica das práticas interativas que envolvem os músicos que a atualizam. Talvez até mesmo o termo intérprete não seja adequado para essa situação em que, por um lado quase não há compositores e por outro, a música só existe na performance. Isto é, o jazz, ${ }^{24}$ por exemplo, não existe no papel (que pode funcionar neste caso quase então somente, enquanto um recurso mnemônico) Trata-se sempre de uma música em ação. Aqui o músico é sempre ao mesmo tempo criador ativo e intérprete de seu próprio discurso apesar das limitações mais ou menos rígidas impostas pelos sistemas que contam com toda uma gramaticalidade que molda as possibilidades do jogo. Trata-se, evidentemente de um jogo com regras. Numa prática como esta é importante ressaltar os aspectos ligados ao necessário engajamento e à presença física e corporal do instrumentista. 0 corpo do músico manifesta a sua vontade de potência. Suas intervenções e enunciados emergem de sua relação íntima com o idioma através de seu instrumento. Só improvisa quem está motivado, quem deseja.

A situação no ambiente da livre improvisação é então mais radical no sentido de que nele não há regras estabelecidas. Há só ação e plano de imanência. Em 
certo sentido os músicos em ação e interação partem do infinito: não há nada formado. Somente forças informes, afetos e intensidades. 0 papel dos músicos numa perfomance como esta do grupo Akronon descrita acima é, a partir da interação, do contato concreto e empírico com o som pensado como força molecular plena de virtualidades e de uma escuta compositora (exercitada ou não por uma atitude consciente de escuta reduzida, conforme recomendação de Rodolfo Caesar) delinear um finito, que, no caso da livre improvisação é uma espécie de continuum indiscernível de estados sonoros temporais provisórios mais ou menos consistentes. Podemos entender assim: o ambiente é o plano de imanência, lugar do infinito, do não formado, do caos, pleno de intensidades e devires. Nele os músicos traçam diagramas que garantem o surgimento de formas, constâncias que vão dar consistência à prática. Assim, a ação dos músicos afasta a idéia de caos criando blocos de sensação significativos (embora muito fluentes e, em maior ou menor grau, instáveis) e consolidando fluxos e ritmos em novas imagens de tempo. Num plano como esse a ativação do desejo é condição necessária. É evidente que o plano de consistência da livre improvisação é um ambiente de alto risco onde, se por um lado, infinitas atualizações podem ocorrer, por outro há o risco de um mergulho no nada indiferenciado. Por isso é importante ressaltar também que o grau de potência deste plano é proporcional às possibilidades técnicas e musicais dos participantes: a intimidade com os materiais, seus dinamismos, suas linhas de força, formas de resistência etc. Como diria Deleuze: só é possível desterritorializar a partir de territórios estabelecidos.

\section{Referências}

BOULEZ, Pierre, Apontamentos de um aprendiz, Stella Moutinho, et al, trad. São Paulo: Perspectiva, 1995 (do original em francês Releves d'apprenti, 1966).

BRITTO, Beatriz de Araújo, Arte e mídia - A ação do grupo Oi Nóis Aqui Traveiz como espaço de resistência e suas recepções na mídia, Tese de doutorado apresentada à PUC-SP, 2007.

CAESAR, Rodolfo, 0 tímpano é uma tela? in Anais do IV Fórum CLM -USP, São Paulo: Ed. ECA, 2004.

CAMPOS, Augusto, Música de Invenção. São Paulo: Perspectiva, 1998.

COSTA, Rogério Luiz Moraes, 0 músico enquanto meio e os territórios da livre improvisação, Tese apresentada ao curso de Doutorado do Programa de Comunicação e Semiótica da PUC-SP, 2002.

DEL POZZO, Maria Helena, Da forma aberta à indeterminação: processos de utilização do acaso na música brasileira para piano, Tese de doutorado apresentada ao IA - Unicamp, 2007.

ECO, Humberto, A obra aberta, Sebastião Uchoa Leite, trad. São Paulo: Perspectiva, 1976 (do original em italiano Opera Aperta, 1958).

HUIZINGA, Johan, Homo Ludens, São Paulo: Perspectiva, 1993.

KOSTELANETZ, Richard. John Cage-Writer - Selected Texts. New York: Cooper Square Press, 2000.

LOCHHEAD, Judy \&t Joseph Auner (Eds.). Postmodern Music / Postmodern Thought. New York \&t London: Routledge, 2002, $372 \mathrm{pp}$.

NATTIEZ, Jean-Jacques (org.), The Boulez-Cage Correspondence/documents collected. Translation Robert Samuels. New York: Syndicate of the University of Cambridge, 1993.

RODRIGUES, Rodrigo Fonseca e, A imagem da escuta: os sites person-to-person e os compositores heterônimos, Tese apresentada ao Curso de Doutorado do Programa de Comunicação e Semiótica da PUC-SP, 2007.

Rogério Luiz Moraes Costa é professor, compositor e performer, integrante e fundador do grupo Akronon de livre improvisação (saxofones e flautas). Fundou e integrou durante 15 anos o grupo de jazz brasileiro Aquilo Del Nisso. Graduado em Licenciatura com Habilitação em Música (1982) no Departamento de Música da ECA-USP onde estudou composição com os professores Willy Correa de Oliveira e Gilberto Mendes. Mestrado no Departamento de Música da ECAUSP com a dissertação: "Suite Improviso - a construção do improviso: composição e interpretação em práticas interativas". Doutorado no Depto.de Comunicação e Semiótica da PUC-SP, com a Tese: "O músico enquanto meio e os territórios da livre improvisação". É, atualmente, professor de matérias teóricas e Coordenador da Graduação no Departamento de Música da ECA-USP. Dá aulas também no curso de pós-graduação do mesmo departamento. 


\section{Notas}

10 grupo é constituido por Edson Ezequiel no violino, Rogério Costa (autor do presente artigo) no saxofone e flauta e Silvio Ferraz no processamento eletrônico.

2 Há hoje em dia inúmeros músicos e grupos que se dedicam à prática da livre improvisação. Estes grupos de músicos-improvisadores ou intérpretescriadores têm origens muito diversas. Muitos vêm de uma prática anterior de improvisação idiomática (jazz, rock, música de tradição não ocidental etc.), outros vêm de uma formação mais vinculada à música erudita ocidental e têm a obra de Cage como uma referência. Deste amplo universo poderiamos citar o guitarrista Derek Bailey, a violista La Donna Smith, os grupos ingleses MIC (Music Improvisation Company) e Joseph Holbrooke, além do grupo brasileiro Akronon do qual fazemos parte, dentre muitos outros.

30 que não significa necessariamente que o próprio Cage assumisse esta idéia. Porém, é evidente a existência de inúmeros músicos e grupos que trabalham com os conceitos de indeterminação, acaso e improvisação e que assumem a obra de Cage como uma importante referência para essa proposta de transformação do papel do intérprete.

4 .... transmutação do acaso estaria na adoção de uma filosofia colorida de orientalismo que encobrisse uma fraqueza fundamental na técnica da composição/.../veneno sutil que destrói qualquer embrião de artesanato/.../o individuo não se sentindo responsável por sua obra/.../eu qualificaria então essa experiência de acaso por inadvertência (BOULEZ, 1966, p.43).

5 A idéia de utilização do acaso e da indeterminação ocorre inicialmente aplicada aos processos de criação em certas obras de Cage. Isso se dá, por exemplo, na obra Music of Changes (1951) onde as alturas, durações e dinâmicas são escolhidas através do uso de cartas derivadas do I Ching. Nesse caso o jogo é exercido pelo próprio compositor. Posteriormente, Cage irá utilizar a idéia de acaso ou indeterminação no momento da execução da obra, instaurando assim o jogo para os intérpretes. 0 nosso interesse se volta para este segundo aspecto.

6 Sobre este assunto já haviamos pontuado em nossa tese que: É interessante notar que os processos da livre improvisação estão muito mais próximos das idéias de Cage, mas as sonoridades resultantes estão mais próximas das obras de Varèse (COSTA, 2003, p.168). Ao mesmo tempo não podemos deixar de ressaltar as semelhanças entre as duas propostas na medida em que Cage também estava menos interessado em criar obras acabadas do que em desencadear ações ou situações musicais imprevistas, que induzissem a uma deslavagem da memória musical e a uma renovação da mente (CAMPOS, 1998, p.161).

7 Este termo é aplicado por Schaeffer no seu "Tratado" para designar uma escuta intencionada para o som propriamente dito e sua fatura como é a escuta de um músico num concerto observando: "o fagote está desafinado...acho que é um problema na palheta..."

80 que os aproximaria da idéia de livre improvisação conforme a descrevemos.

9 Não é o caso de muitas das obras mais antigas de Cage tais como as Constructions para instrumentos de percussão, as Sonatas e Interlúdios para piano preparado e muitas outras.

10 A respeito desta questão segundo Yves Bosseur, existem ainda as partituras de texto que substituem as partituras tradicionais. Ele exemplifica este tipo de proposta que ocorre na obra Aus den sieben Tagen (1968) de K. Stockhausen: Através destas partituras de texto, o compositor se torna o catalizador de uma ação onde as condições de base são, certamente, ainda indefinidas por ele, mas aonde a partitura, objeto colocado entre 0 executante e seus parceiros, desaparece para transformar-se em um roteiro de ações e reações, subjacente a um momento de prática musical (apud DAL POZZO, 2007, p. 144).

11 Este tipo de atitude parece remeter a uma nostalgia de um tempo histórico onde não havia a separação entre a figura do intérprete e o compositor. 0 músico exercia ao mesmo tempo e de maneira indissolúvel os dois papéis.

12 Estas categorizações têm um objetivo meramente metodológico. Obviamente não há pensamento musical puramente rítmico ou textural. Tudo acontece em simultaneidade.

13 É importante salientar que a idéia de uma escuta "pura", totalmente descondicionada que subjaz ao conceito de escuta reduzida de Schaeffer, parece hoje totalmente descartada. Há um consenso no sentido de afirmar que "todo universo complexo e dinâmico da escuta não se restringe apenas à atividade de ouvir sons (RODRIGUES, 2007, p. 97)". Já para o compositor e teórico Rodolfo Caesar, a escuta reduzida ou acusmática é como "um exercício de aquecimento e de alongamento, para que não entremos completamente despreparados nos horizontes elásticos da escuta (CAESAR, 2004, p. 25)".

14 Esse mergulho significa também e principalmente uma imersão corporal. Trata-se de um contato direto, não mediado do corpo do músico (seus sentidos, sensações, habilidade etc.) com a matéria sonora em movimento.

15 Que neste caso deixam de ser intérpretes no sentido tradicional do termo.

16 Neste sentido o jogo de Cage é um jogo de possibilidades e não de virtualidades.

17 É preciso entender que o virtual - na perspectiva adotada por Deleuze - é o lugar do desejo, da potência, das forças, do devir e do dinamismo ilimitado. Nele não há ainda a matéria formada, mas sim diferenciação paradoxal e imanente.

18 A gravação se encontra na biblioteca da PUC-SP como um anexo da tese.

19 Percebe-se aqui e, mais ainda, nós enquanto participantes das performances o sabemos, que o material produzido pelo músico ao lado se impõe enquanto uma espécie de provocação - action-reaction music. A nós cabe reagir a este material sempre e a todo o momento. Nossa resposta vai gerar uma réplica e assim por diante. Assim se instala um ciclo virtuoso e produtivo que vive e se mantém através desta série incessante de perguntas, respostas, comentários, concordâncias, discordâncias, etc.

20 Esta transição se percebe enquanto tal a posteriori uma vez que, durante a performance, não há nenhuma intenção estrutural explícita.

21 Esta afirmação parte de uma observação genérica e se refere ao intérprete fundamentalmente ligado a uma tradição de execução mediada por partitura. Obviamente, há exceções no amplo universo de intérpretes e certamente haverá alguns que se envolvem de maneira efetiva com as propostas conceituais existentes nestas obras e desenvolvem toda uma postura nova e diferenciada com relação à prática musical.

22 Talvez as intenções de Cage estejam mais voltadas para um questionamento do conceito de composição musical ou mesmo da própria escuta. Isto é, saber quando a escuta se torna musical.

23 Se é que isso é possivel para um compositor, conforme já comentamos anteriormente quando comparamos as origens das duas propostas abordadas.

24 Pensamos aqui nas manifestações mais tradicionais deste gênero de música que se realiza principalmente através da improvisação (o jazz histórico que nasce no ragtime e percorre os estilos tradicionais, principalmente o swing, be-bop, o cool jazz, o hard bop e o free jazz). Não pensamos nos gêneros mais hibridos contemporâneos em que algumas das caracteristicas fundamentais do estilo se dissolvem. 